\title{
Pengaruh Tiang Terhadap Kapasitas Dukung Pelat dan Modulus Reaksi Tanah-Dasar pada Tanah Gambut
}

\author{
The Effect of Pile on the Bearing Capacity of the Plate and the Modulus of Subgrade Reaction \\ on Peat Soil
}

\author{
Aazokhi Waruwu ${ }^{1, *}$, Santo Yanri Pardosi ${ }^{2}$ \\ 1 Jurusan Teknik Sipil, Institut Teknologi Medan, Jl. Gedung Arca No. 52, Medan, Indonesia \\ ${ }^{2}$ Jurusan Teknik Sipil, Institut Teknologi Medan, Jl. Gedung Arca No. 52, Medan, Indonesia
}

\author{
* Penulis korespondensi : azokhiw@gmail.com \\ Tel.: +62-61-736-3771; fax.:+62-61-734-7954 \\ Diterima: 19 Agustus 2021; Direvisi: 31 Oktober 2021; Disetujui: 31 Oktober 2021 \\ DOI: 10.25299/saintis2021.vol21(02).7546
}

\begin{abstract}
Abstrak
Lahan gambut yang tersebar luas dapat menghambat pengembangan infrastruktur, karena tanah ini termasuk jenis tanah bermasalah sebagai tanah dasar. Tanah gambut memiliki penurunan yang tinggi dan kapasitas dukung rendah. Tiang perkuatan memiliki potensi dalam mengurangi penurunan, meningkatkan kapasitas dukung dan modulus reaksi tanah-dasar. Penelitian ini bertujuan untuk mengetahui kapasitas dukung dan modulus reaksi tanah-dasar pada pelat yang diperkuat tiang tunggal. Penelitian dilakukan pada bak uji yang diisi dengan tanah gambut sedalam $50 \mathrm{~cm}$. Tiang dari bahan bambu, kayu, dan beton dipancang dalam tanah gambut. Panjang tiang yang digunakan adalah 10-40 cm dan diameter pelat beton sebesar $10 \mathrm{~cm}$. Uji beban pelat dilakukan pada pelat tanpa dan dengan perkuatan tiang untuk mendapatkan nilai kapasitas dukung dan modulus reaksi tanah-dasar. Hasil penelitian didapatkan bahwa jenis dan panjang tiang berpengaruh pada nilai kapasitas dukung, defleksi, dan modulus reaksi tanah-dasar. Tiang yang lebih panjang menghasilkan kapasitas dukung dan modulus reaksi tanah-dasar yang tinggi dan defleksi yang semakin rendah. Kapasitas dukung meningkat $20 \%$ untuk tiang bambu, $22 \%$ untuk tiang kayu, dan $25 \%$ untuk tiang beton. Peningkatan modulus reaksi tanah-dasar didapatkan pada defleksi pelat maksimum $20 \%$ dari diameter pelat. Peningkatan tertinggi untuk tiang bambu sebesar $103 \%$, tiang kayu $128 \%$, dan tiang beton sebesar $160 \%$. Panjang tiang yang memberikan hasil maksimal dalam mereduksi penurunan, meningkatkan kapasitas dukung, dan meningkatkan modulus reaksi tanah-dasar adalah $80 \%$ dari tebal lapisan tanah gambut. Nilai modulus reaksi tanah-dasar semakin tinggi seiring dengan peningkatan kapasitas dukung dan pengurangan defleksi.
\end{abstract}

Kata Kunci: Tiang, Kapasitas dukung, Defleksi, Modulus reaksi tanah dasar

\begin{abstract}
Widespread peatlands can prevent infrastructure development, because this soil is classified as problematic soil types as subgrade. Peat soil has high settlement and low bearing capacity. Reinforcement pile has the potential to reduce settlement, increase bearing capacity and modulus of subgrade reaction. This study aims to determine the bearing capacity and modulus of subgrade reaction on a single pile reinforced slab. The study was conducted in a test box filled with peat soil as deep as $50 \mathrm{~cm}$. Pile made of bamboo, wood, and concrete are driven in peat soil. The length of the pile used is $10-40 \mathrm{~cm}$ and the diameter of the concrete slab is $10 \mathrm{~cm}$. The plate load test was conducted on slabs without and with reinforced piles to obtain the value of the bearing capacity and modulus of subgrade reaction. The results showed that the type and length of the pile affect the value of the bearing capacity, deflection, and modulus of subgrade reaction. Longer piles result in higher bearing capacity and modulus of subgrade reaction and lower deflection. The bearing capacity increased by $20 \%$ for bamboo pile, $22 \%$ for wooden pile, and $25 \%$ for concrete pile. An increase in the modulus of subgrade reaction is obtained at a maximum slab deflection of $20 \%$ of the slab diameter. The highest increase for bamboo pile is 103\%, wooden pile is 128\%, and concrete pile is $160 \%$. The length of the pile that gives maximum results in reducing settlement, increasing bearing capacity, and increasing the modulus of subgrade reaction is $80 \%$ of the thickness of the peat soil layer. The value of the modulus of subgrade reaction is higher as the bearing capacity increases and the deflection decreases.
\end{abstract}

Keywords: Pile, Bearing Capacity, Deflection, Modulus of subgrade reaction

\section{PENDAHULUAN}

Lahan gambut dan rawa tersebar luas di wilayah Indonesia. Menurut Syarif et al. [1], lahan gambut dan rawa ada sekitar $30 \%$ dari wilayah Indonesia, sehingga keberadaan lahan gambut dapat menghambat perkembangan infrastruktur. Ini disebabkan karena jenis tanah gambut tergolong sebagai tanah yang bermasalah apabila dimanfaatkan sebagai tanah dasar konstruksi.
Tanah organik yang diklasifikasi sebagai tanah gambut berserat apabila kandungan organik lebih tinggi dari $75 \%$ dan kadar serat di atas $20 \%$ [2]. Tanah gambut berserat memiliki kadar air abu rendah, pemampatan tinggi yang sebagian besar terdiri dari pemampatan sekunder, dan kapasitas dukung rendah. Upaya perbaikan tanah gambut terus dilakukan, beberapa di antaranya dengan menggunakan tiang-tiang perkuatan. Penggunaan tiang berupa kolom semen yang dipasang dalam 
lapisan tanah gambut dapat mengurangi pemampatan dan memperkecil penurunan [3].

Berdasarkan analisis dan penelitian yang dilakukan Yusuf \& Aryanto [4], penggunaan tiang cerucuk pada pelat beton didapatkan memiliki kemampuan untuk meningkatkan kapasitas dukung. Penambahan panjang tiang berpengaruh pada peningkatan kapasitas dukung pelat pada tanah gambut.

Faktor lain yang mempengaruhi kapasitas dukung dan penurunan adalah konfigurasi tiang, baik lebar maupun jarak tiang, karena ini berhubungan dengan efisiensi tiang [5]. Nilai efisiensi tiang semakin meningkat pada rasio jarak dengan diameter tiang yang semakin besar [6]. Kapasitas dukung maksimum didapatkan pada kelompok tiang dengan jarak sebesar 3,5 dari diameter. Jumlah tiang cerucuk dan kulit dari tiang cerucuk memiliki pengaruh pada peningkatan kapasitas dukung tanah gambut [7].

Waruwu et al. [8] meneliti pembebanan pelat dengan perkuatan tiang pada tanah gambut. Hasil penelitian ini menunjukkan bahwa tiang-tiang yang memperkuat pelat dapat mengurangi penurunan, tiang dengan panjang $25 \mathrm{~cm}$ untuk tebal gambut 50 cm lebih efektif dalam mereduksi penurunan. Ini berarti panjang tiang minimum adalah setengah dari tebal lapisan tanah. Namun, hal ini perlu pertimbangan lebar pelat dan jumlah tiang yang digunakan.

Tiang-tiang yang dipasang pada pelat cukup mampu mengurangi baik penurunan maupun defleksi pelat, tiang monolit dengan pelat lebih stabil dan kaku dalam mendukung beban yang bekerja [9].

Penambahan tiang di bawah pelat memiliki fungsi untuk menahan beban, mengurangi penurunan konsolidasi, meningkatkan kekakuan dari pelat, dan menjamin kestabilan konstruksi di atasnya [10]. Tiang-tiang yang dipancang pada tanah gambut dapat meningkatkan kapasitas dukung [11]. Perubahan panjang tiang lebih berpengaruh dalam hal reduksi lendutan dibandingkan dengan perubahan jarak tiang [12].

Peningkatan modulus reaksi tanah-dasar dapat dilakukan dengan perkuatan tiang pada pelat, selain itu tiang-tiang dapat mengurangi penurunan [13]. Tiang yang dipasang monolit lebih efektif dari tiang tidak monolit dengan pelat.

Tiang perkuatan pada tanah gambut yang digunakan pada penelitian terdahulu terdiri dari kolom semen, tiang cerucuk dengan pelat beton, kelompok tiang beton, dan tiang beton monolit dengan pelat. Hasil-hasil penelitian telah menunjukkan peningkatan kapasitas dukung, modulus reaksi tanah-dasar, dan pengurangan pemampatan, penurunan, defleksi pelat pada tanah gambut.

Berdasarkan uraian di atas, maka perlu dilakukan penelitian pada penggunaan tiang perkuatan yang dipasang monolit dengan pelat. Tiang-tiang dibedakan berdasarkan variasi panjang untuk mengetahui pengaruhnya pada nilai daya dukung dan modulus reaksi tanah-dasar. Perubahan panjang dan ikatan tiang dengan pelat memiliki pengaruh yang lebih dominan dalam mereduksi penurunan daripada perubahan jarak tiang [14]. Tiang-tiang yang digunakan berupa tiang beton dengan perbandingan dari jenis tiang bambu dan tiang kayu. Tinjauan dilakukan pada tiang tunggal yang monolit dengan pelat beton dan perubahan panjang.

Tujuan penelitian ini adalah untuk mengetahui peningkatan kapasitas dukung pelat akibat perubahan panjang tiang, untuk menentukan modulus reaksi tanah-dasar pada pelat yang didukung oleh tiang, dan untuk mengetahui hubungan kapasitas dukung dengan modulus reaksi tanah-dasar akibat penambahan tiang.

\section{Kapasitas Dukung}

Kapasitas dukung merupakan kemampuan tanah dalam mendukung beban pondasi dari struktur yang bekerja di atasnya, sedangkan kapasitas dukung ultimit $\left(\mathrm{q}_{\mathrm{u}}\right)$ merupakan beban maksimum per satuan luas (P/A) pada tanah yang mendukung beban tanpa mengalami keruntuhan [15].

Menurut Das [16], kapasitas dukung dapat ditentukan dari hasil uji beban langsung pada pelat berbentuk lingkaran atau bujur sangkar. Kapasitas dukung ultimit diperoleh dari perpotongan garis singgung berbentuk linier awal dan linier akhir dari hubungan beban dengan penurunan [17].

\section{Modulus Reaksi Tanah-Dasar}

Modulus reaksi tanah-dasar merupakan konstanta matematis yang menunjukkan kekakuan fondasi [15]. Hasil uji beban pelat berupa garis lurus, apabila didapatkan kurva yang melengkung, maka modulus reaksi tanah-dasar ditentukan dari kemiringan garis yang ditarik dari titik awal kurva sebagai modulus awal $\left(\mathrm{k}_{\mathrm{awal}}\right)$ atau sampai pada titik dengan tekanan dan defleksi atau penurunan ratarata sebagai modulus sekan ( $\mathrm{k}_{\text {sekan }}$ ). Modulus reaksi tanah-dasar $(\mathrm{k})$ didefinisikan sebagai perbandingan tekanan $(\sigma)$ atau beban per satuan luas dengan defleksi $(\delta)$ atau penurunan rata-rata (Persamaan 1).

$$
k=\sigma / \delta
$$

Pemasangan tiang pada pelat dapat menambah modulus reaksi tanah-dasar, ini dinamakan sebagai tambahan modulus reaksi tanah-dasar $(\Delta \mathrm{k})$. Dengan demikian, modulus reaksi tanah-dasar pada pelat yang diperkuat tiang dapat disebut sebagai modulus reaksi tanah-dasar ekivalen ( $\left.k^{\prime}\right)$ yang besarnya didapatkan dari jumlah modulus reaksi tanah-dasar $(\mathrm{k})$ dengan tambahan modulus reaksi tanah-dasar $(\Delta \mathrm{k})$, seperti terlihat pada Persamaan (2) [13].

$k^{\prime}=k+\Delta k$ 
Menurut Bowles [18], nilai $\mathrm{k}$ dapat ditentukan berdasarkan kapasitas dukung ultimit. Hubungan nilai modulus reaksi tanah-dasar $(\mathrm{k})$ dengan dukung ultimit $\left(\mathrm{q}_{\mathrm{u}}\right)$ seperti terlihat pada Persamaan (3).

$k=40 q_{u}$

\section{METODOLOGI}

Tanah yang digunakan dalam penelitian ini adalah tanah gambut yang diambil dari Bagansiapiapi-Riau. Bahan pelat dari beton berukuran diameter $10 \mathrm{~cm}$ dengan tebal $2 \mathrm{~cm}$ diberi tulangan kawat. Bahan tiang terdiri dari bambu, kayu, dan beton. Kayu dari material kayu laut diambil dari Belawan-Sumatera Utara dan bambu diambil dari daerah Humbang HasundutanSumatera Utara.

Bahan pelat dan tiang yang digunakan dalam penelitian ini ditunjukkan pada Gambar 1. Tiang beton dicor menggunakan pipa PCV dan diberi tulangan kawat diameter (d) $2 \mathrm{~mm}$ sebanyak 3 batang setiap tiang. Tiang-tiang yang digunakan berdiameter $2 \mathrm{~cm}$ dengan ukuran panjang (L) 10 $\mathrm{cm}, 20 \mathrm{~cm}, 30 \mathrm{~cm}$, dan $40 \mathrm{~cm}$. Pelat dicor monolit dengan tiang beton. Tiang bambu dan kayu juga demikian, diikat dengan tulangan kawat dan dicor monolit dengan pelat.

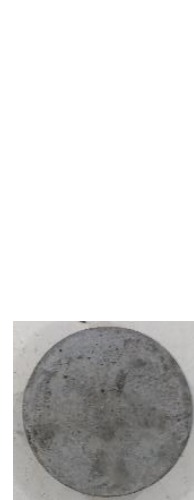

(a)

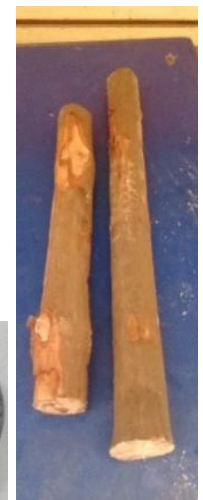

(b)

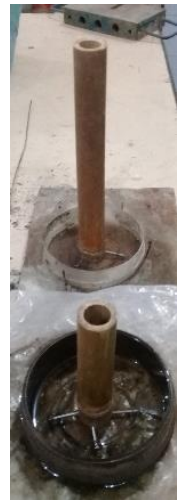

(c)

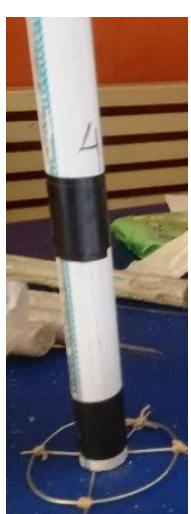

(d)
Gambar 1. Bahan Pelat dan Tiang: (a) Pelat Beton; (b) Tiang Kayu, (c) Tiang Bambu, (d) Tiang Beton

Tanah gambut dipadatkan setiap tebal $10 \mathrm{~cm}$ dengan mengacu pada kepadatan tanah gambut di lokasi pengambilan. Tingkat kepadatan setiap lapis dapat diketahui melalui uji core cutter yang dilakukan pada titik-titik tertentu setiap lapisnya. Tebal keseluruhan lapisan tanah gambut adalah 50 $\mathrm{cm}$.

Tanah dijenuhkan dengan mengalirkan air melalui pipa-pipa pvc yang diletakkan di setiap sudut dan dasar bak uji. Tanah dibiarkan selama 1 minggu untuk menunggu air meresap dalam butiran tanah. Pelat tanpa tiang dan pelat dengan tiang siap untuk dipancang dalam lapisan tanah seperti terlihat dalam Gambar 2.

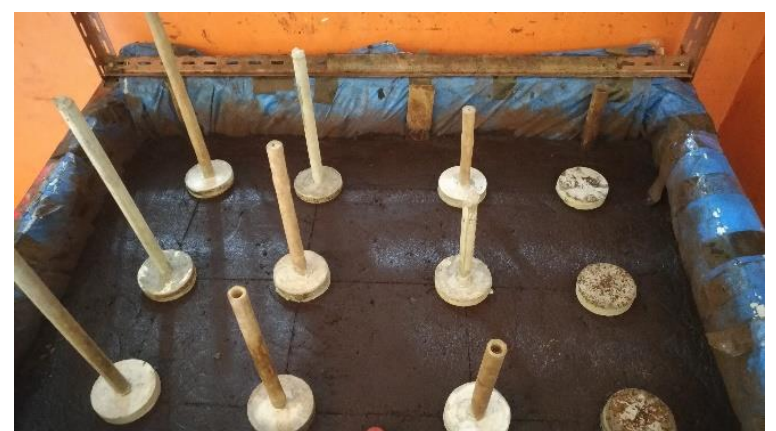

Gambar 2. Persiapan Pemancangan Tiang Perkuatan Pelat

Pelat tanpa tiang dan dengan tiang yang telah dipancang selama minimal 3 hari diuji dengan menerapkan beban dari pelat melalui frame pembebanan seperti terlihat pada Gambar 3 . Beban-beban diberikan secara bertahap dan setiap tahapan dilakukan pembacaan penurunan melalui dial gauge yang dipasang di tengah-tengah pelat. Penambahan beban dilakukan apabila penurunan telah mencapai 0,03 mm setiap menit.

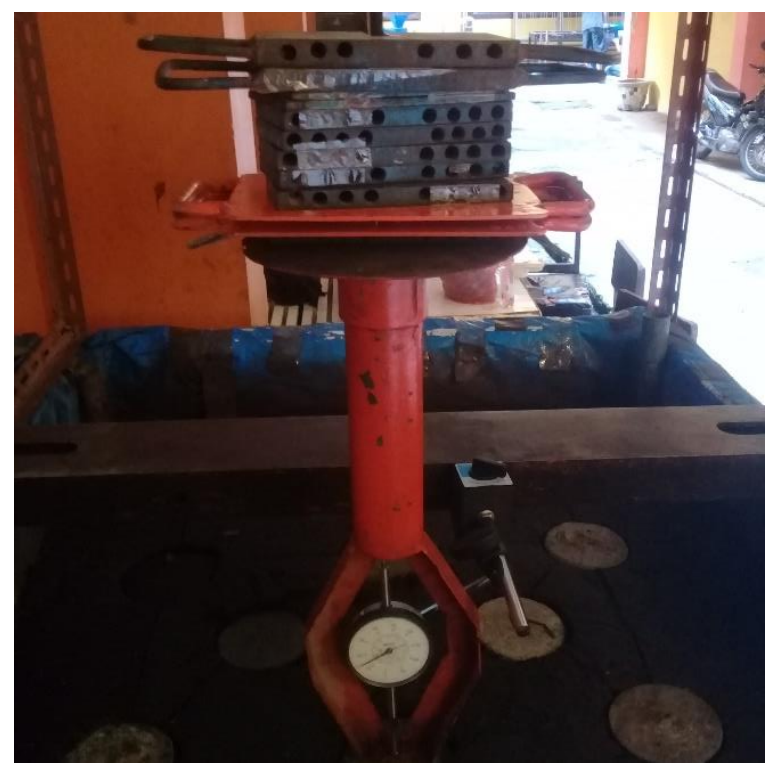

Gambar 3. Uji Beban Pelat

Tekanan $(\sigma)$ yang bekerja pada pelat didapatkan dari beban dibagi luas pelat. Berdasarkan hubungan tekanan dengan penurunan didapatkan nilai kapasitas dukung pelat dan defleksi $(\delta)$ dari perpotongan kedua garis singgung. Grafik yang sama digunakan untuk menentukan modulus reaksi tanah-dasar $(k)$ dari perbandingan tekanan $(\sigma)$ dengan defleksi $(\delta)$.

\section{HASIL DAN DISKUSI}

Penelitian ini menampilkan hasil uji beban pelat yang diperkuat tiang tunggal dari bahan bambu, kayu, dan tiang beton. Ukuran panjang dan diameter tiang dibuat sama. Kondisi batas utamanya pada diameter pelat dan diameter tiang yang tetap, tebal lapisan gambut tetap dengan kondisi kepadatan mendekati konstan, dan ukuran 
bak uji yang tetap. Hal yang berbeda adalah jenis tiang dan panjang tiang.

Hasil dan pembahasan yang dipaparkan dalam penelitian ini dibatasi pada hubungan $\delta_{o}$ dan $\delta_{\mathrm{o}} / \delta$, cara mendapatkan kapasitas dukung, hasil kapasitas dukung pelat tanpa tiang dan dengan tiang, hubungan panjang tiang dengan defleksi, pengaruh panjang tiang terhadap kapasitas dukung, hubungan $\mathrm{k}^{\prime}$ dan $\delta_{\mathrm{o}}$ pada setiap panjang dan jenis tiang, pengaruh panjang tiang terhadap modulus reaksi tanah-dasar, dan hubungan kapasitas dukung dengan modulus reaksi tanah-dasar.

\section{Hasil Uji Beban Pelat}

Hasil uji beban pelat dengan tiang dan pelat tanpa tiang untuk masing-masing jenis tiang ditunjukkan dalam hubungan $\delta_{\mathrm{o}}$ dan $\delta_{\mathrm{o}} / \delta$ pada Gambar 4. Nilai $\delta_{0}$ merupakan penurunan atau defleksi pelat tanpa tiang, sedangkan $\delta$ merupakan penurunan atau defleksi pelat dengan tiang.
Hasil uji beban pada ketiga jenis tiang memperlihatkan rasio penurunan yang signifikan pada tiang dengan panjang $40 \mathrm{~cm}$, sedangkan pada tiang dengan panjang $10-30 \mathrm{~cm}$ memperlihatkan hubungan yang hampir sama pada rasio penurunan. Ini menunjukkan bahwa reduksi penurunan pada variasi panjang tiang 10-30 cm tidak jauh berbeda.

Rasio penurunan terlihat signifikan di awalawal pembebanan, namun pada penurunan pelat di atas 0,02 $\mathrm{m}$ didapatkan rasio penurunan yang hampir konstan. Perilaku tiang kayu terlihat berbeda dengan jenis tiang lainnya. Tiang kayu menunjukkan peningkatan rasio penurunan seiring dengan panjang tiang. Ini kemungkinan berbeda karena tingkat kekasaran permukaan selimut dari material kayu lebih tinggi dari material lainnya. Interaksi antar tanah dengan selimut tiang kayu yang semakin tinggi akibat kekasaran permukaannya dapat meningkatkan kuat gesek tiang, sehingga penurunan semakin kecil.

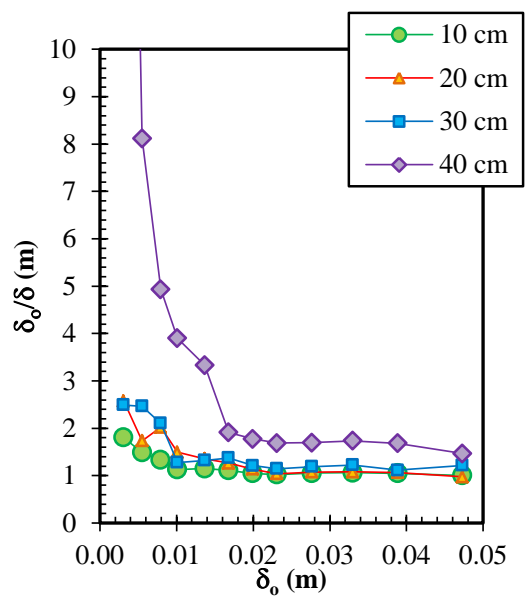

(a)

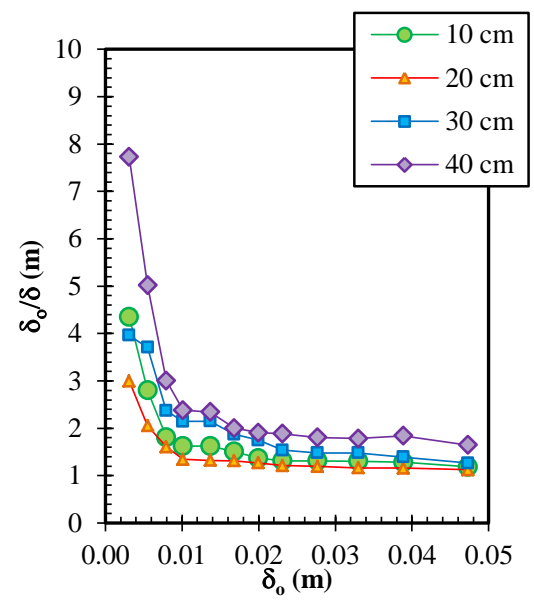

(b)

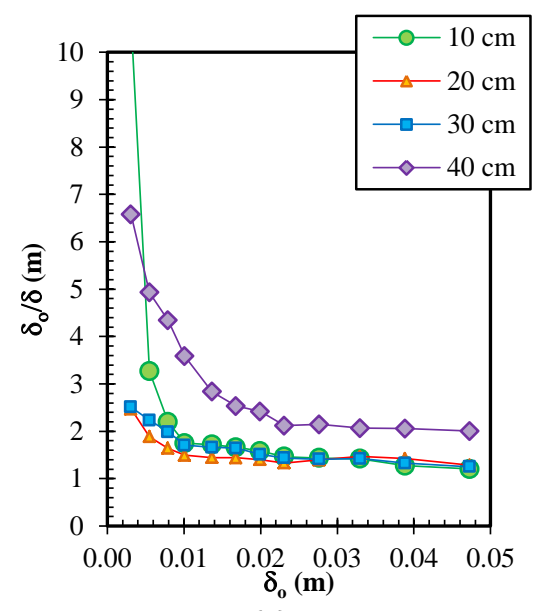

(c)

Gambar 4. Hubungan $\delta_{o}$ dan $\delta_{o} / \delta$ pada Tiang: (a) Beton; (b) Kayu, dan (c) Bambu

Hasil uji beban pelat didapatkan penurunan pada masing-masing penambahan beban untuk setiap perubahan panjang tiang. Tekanan didapatkan dari beban per satuan luas bidang pelat yang digunakan. Hubungan tekanan dengan penurunan atau defleksi pelat ditunjukkan pada Gambar 5. Perpotongan kedua garis singgung linier awal dan akhir menghasilkan nilai kapasitas dukung ultimit $\left(\mathrm{q}_{\mathrm{u}}\right)$ dan defleksi $(\delta)$.

Cara yang sama dilakukan pada setiap jenis dan panjang tiang. Hasil analisis kapasitas dukung pelat tanpa tiang dan dengan tiang ditunjukkan pada Tabel 1. Kapasitas dukung pelat tanpa tiang sebesar $6 \mathrm{kPa}$. Kapasitas dukung pelat dengan tiang bambu antara 6,9-7,6 $\mathrm{kPa}$, tiang kayu antara 7-7,7 $\mathrm{kPa}$, dan tiang beton antara 7,3-7,8 $\mathrm{kPa}$.
Tekanan $(\mathrm{kPa})$

$\begin{array}{lllllllll}0.1 & 0.2 & 0.4 & 0.8 & 1.6 & 3.2 & 6.4 & 12.8 & 25.6\end{array}$

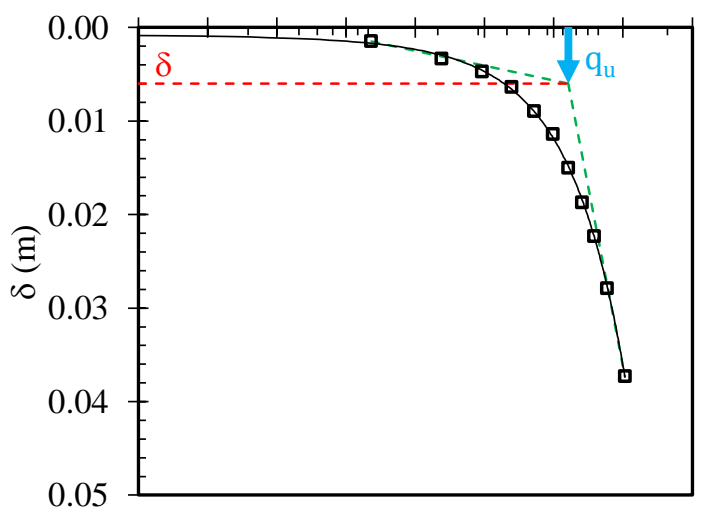

Gambar 5. Cara Menentukan Kapasitas Dukung 
Tabel 1. Kapasitas Dukung Pelat Tanpa dan Dengan Tiang

\begin{tabular}{cccc}
\hline $\begin{array}{c}\text { Panjang } \\
\text { tiang }(\mathbf{c m})\end{array}$ & $\begin{array}{c}\mathbf{q u}_{\mathbf{u}} \mathbf{b a m b u} \\
(\mathbf{k P a})\end{array}$ & $\begin{array}{c}\mathbf{q}_{\mathbf{u}} \mathbf{k a y u} \\
\mathbf{( k P a )}\end{array}$ & $\begin{array}{c}\mathbf{q}_{\mathbf{u}} \mathbf{b e t o n} \\
\mathbf{( k P a )}\end{array}$ \\
\hline Tanpa tiang & 6,0 & 6,0 & 6,0 \\
10 & 6,9 & 7,0 & 7,3 \\
20 & 7,0 & 7,2 & 7,4 \\
30 & 7,3 & 7,4 & 7,6 \\
40 & 7,6 & 7,7 & 7,8 \\
\hline
\end{tabular}

Defleksi berupa penurunan pelat dalam kondisi kapasitas dukung ultimit untuk masingmasing jenis dan panjang tiang diperlihatkan pada Gambar 6. Perubahan defleksi pelat terlihat mulai mengalami perubahan pada tiang dengan panjang $30 \mathrm{~cm}$ dan perubahan defleksi yang signifikan didapatkan pada tiang dengan panjang $40 \mathrm{~cm}$ atau $80 \%$ dari tebal lapisan tanah. Hasil ini berbeda dengan penelitian Waruwu et al. [8], reduksi penurunan yang signifikan didapatkan pada panjang tiang $50 \%$ dari tebal lapisan tanah gambut. Ini dapat berbeda karena tiang yang digunakan dalam penelitian ini merupakan tiang tunggal. Defleksi pelat yang diperkuat tiang beton lebih kecil dibandingkan dengan tiang bambu dan tiang kayu. Defleksi pelat yang lebih kecil memperlihatkan peningkatan pada kapasitas dukung pelat.

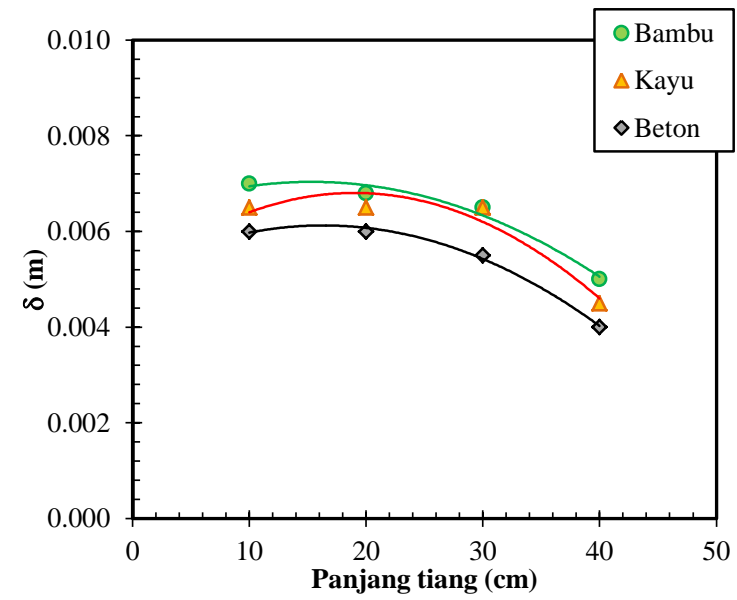

Gambar 6. Defleksi Pelat pada Kapasitas Dukung Ultimit

\section{Pengaruh Panjang Tiang Terhadap Kapasitas Dukung}

Pengaruh panjang tiang terhadap kapasitas dukung pelat pada setiap jenis tiang yang berbeda dapat dilihat pada Gambar 7. Kapasitas dukung pelat dengan tiang dipengaruhi oleh panjang tiang dan jenis material tiang yang digunakan. Terlihat bahwa tiang yang lebih panjang memberikan dukung yang kuat pada pelat, sehingga kapasitas dukung semakin meningkat. Hal ini menunjukkan peningkatan kapasitas gesek yang semakin tinggi seiring dengan penambahan panjang tiang.

Berdasarkan jenis material tiang, nilai kapasitas dukung pelat yang diperkuat tiang beton lebih tinggi dari tiang kayu dan tiang bambu. Ini menunjukkan tiang dari beton lebih kokoh dan kuat dalam memikul beban di atas pelat. Tiang beton yang monolit dengan pelat meningkatkan kekakuan dan kestabilan dalam mendukung beban [9].

Peningkatan kapasitas dukung pelat akibat perkuatan tiang dapat dilihat pada Tabel 2 . Peningkatan kapasitas dukung pelat dengan tiang bambu didapatkan sebesar $15-27 \%$ atau rata-rata $20 \%$, tiang kayu sebesar $17-28 \%$ atau rata-rata $22 \%$, dan tiang beton $22-30 \%$ dengan rata-rata $25 \%$. Tiang yang memperkuat pelat memberikan peningkatan kapasitas dukung pada tanah gambut [11]. Tiang yang lebih panjang memberikan pengaruh yang signifikan pada peningkatan kapasitas dukung [12].

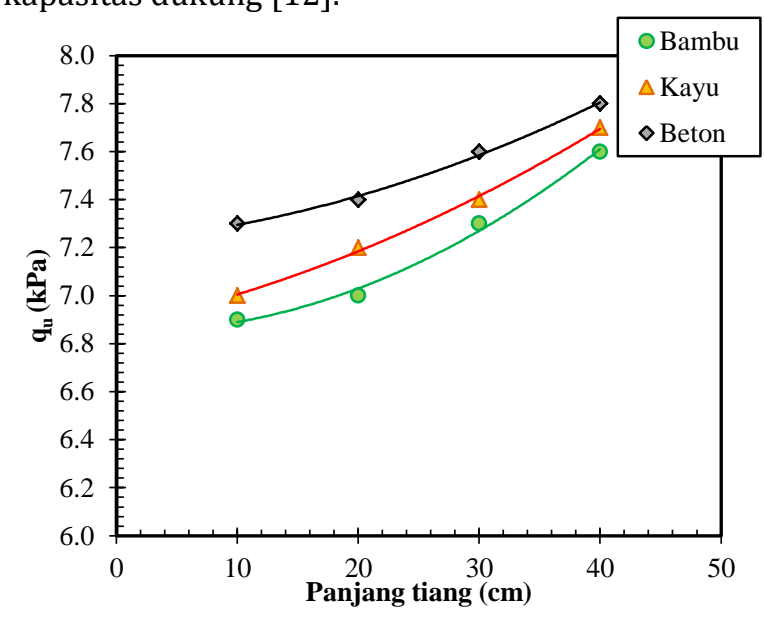

Gambar 7. Kapasitas Dukung Pelat pada Setiap Panjang Tiang

Tabel 2. Peningkatan Kapasitas Dukung Pelat Akibat Perkuatan Tiang

\begin{tabular}{|c|c|c|c|}
\hline \multirow{2}{*}{$\begin{array}{c}\text { Panjang } \\
\text { tiang }(\mathrm{cm})\end{array}$} & \multicolumn{3}{|c|}{ Peningkatan $\mathrm{q}_{\mathrm{u}}(\%)$} \\
\hline & $\begin{array}{c}\text { Tiang } \\
\text { bambu }\end{array}$ & $\begin{array}{l}\text { Tiang } \\
\text { kayu }\end{array}$ & $\begin{array}{l}\text { Tiang } \\
\text { beton }\end{array}$ \\
\hline 10 & 15 & 17 & 22 \\
\hline 20 & 17 & 20 & 23 \\
\hline 30 & 22 & 23 & 27 \\
\hline 40 & 27 & 28 & 30 \\
\hline Rata-rata (\%) & 20 & 22 & 25 \\
\hline
\end{tabular}

\section{Pengaruh Panjang Tiang Terhadap Modulus Reaksi Tanah-Dasar}

Perbandingan dengan tekanan dan defleksi $(\delta)$ atau penurunan pada setiap penambahan beban untuk setiap panjang dan jenis tiang menghasilkan kurva modulus reaksi ekivalen ( $\left.\mathrm{k}^{\prime}\right)$ dengan defleksi pada pelat tanpa tiang $\left(\delta_{0}\right)$ seperti pada Gambar 8 . Nilai $\mathrm{k}^{\prime}$ terlihat tinggi di awal-awal pembebanan dan semakin konstan pada nilai $\delta_{0}$ di atas $0,02 \mathrm{~m}$, nilai ini sebanding dengan $20 \%$ dari diameter pelat. Ini dapat diartikan bahwa modulus reaksi tanah dasar lebih tinggi pada penurunan maksimum $20 \%$ dari diameter pelat.

Secara keseluruhan panjang tiang berpengaruh pada peningkatan nilai $\mathrm{k}^{\prime}$, namun pengaruh tertinggi ditunjukkan pada tiang dengan panjang $40 \mathrm{~cm}$ atau sebanding dengan $80 \%$ tebal lapisan gambut. Akan tetapi, untuk tiang kayu didapatkan bahwa tiang dengan panjang $30 \mathrm{~cm}$ 
memperlihatkan pengaruh yang cukup baik dalam meningkatkan nilai k'.

Nilai modulus reaksi tanah-dasar $(\mathrm{k})$ pada pelat tanpa tiang dengan tiang ditunjukkan dalam Tabel 3. Nilai k diperoleh dari tekanan per defleksi. Nilai $\mathrm{k}$ ini merupakan modulus awal yang ditentukan dari kemiringan garis yang ditarik dari titik awal kurva [15]. Nilai $\mathrm{k}$ pada pelat yang diperkuat tiang bambu antara $989-1520 \mathrm{kPa} / \mathrm{m}$, tiang kayu antara $1077-1711 \mathrm{kPa} / \mathrm{m}$, dan tiang beton antara $1217-1950 \mathrm{kPa} / \mathrm{m}$. Nilai k pelat yang diperkuat tiang lebih tinggi dari nilai pelat (750 $\mathrm{kPa} / \mathrm{m})$.

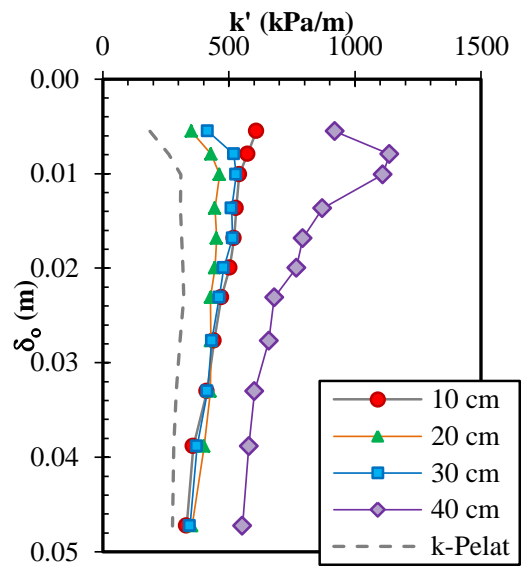

(a)

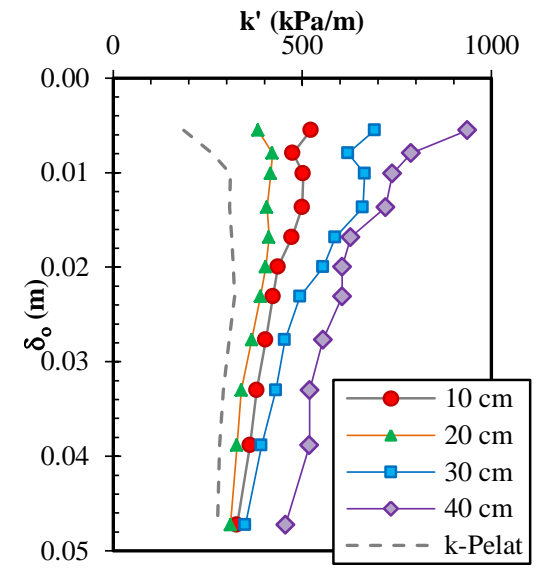

(b)

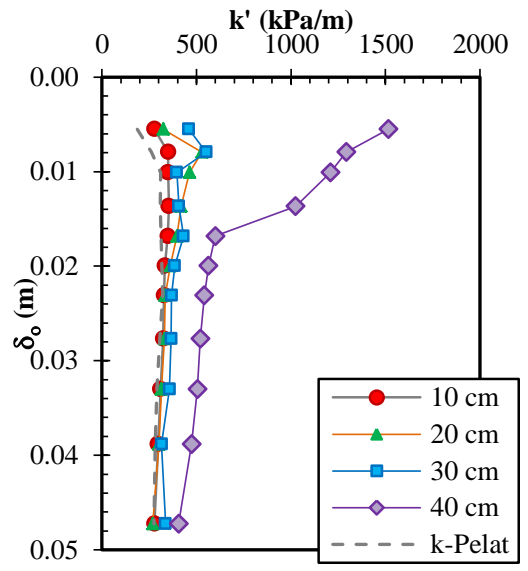

(c)

Gambar 8. Hubungan k' dan $\delta_{o}$ pada Setiap Panjang dan Jenis Tiang: (a) Bambu; (b) Kayu, (c) Beton

Tabel 3. Modulus Reaksi Tanah-Dasar pada Pelat Tanpa dan Dengan Tiang

\begin{tabular}{cccc}
\hline $\begin{array}{c}\text { Panjang } \\
\text { tiang }(\mathbf{c m})\end{array}$ & $\begin{array}{c}\mathbf{k} \text { bambu } \\
\mathbf{( k P a} / \mathbf{m})\end{array}$ & $\begin{array}{c}\mathbf{k} \mathbf{k a y u} \\
\mathbf{( k P a / m )}\end{array}$ & $\begin{array}{c}\mathbf{k} \text { beton } \\
\mathbf{( k P a} / \mathbf{m})\end{array}$ \\
\hline Tanpa tiang & 750 & 750 & 750 \\
10 & 986 & 1077 & 1217 \\
20 & 1029 & 1108 & 1233 \\
30 & 1123 & 1233 & 1382 \\
40 & 1520 & 1711 & 1950 \\
\hline
\end{tabular}

Pengaruh panjang tiang terhadap modulus reaksi tanah-dasar dapat dilihat pada Gambar 9. Panjang tiang perkuatan berpengaruh pada nilai $\mathrm{k}$. Tiang yang semakin panjang menunjukkan nilai $\mathrm{k}$ yang semakin tinggi.

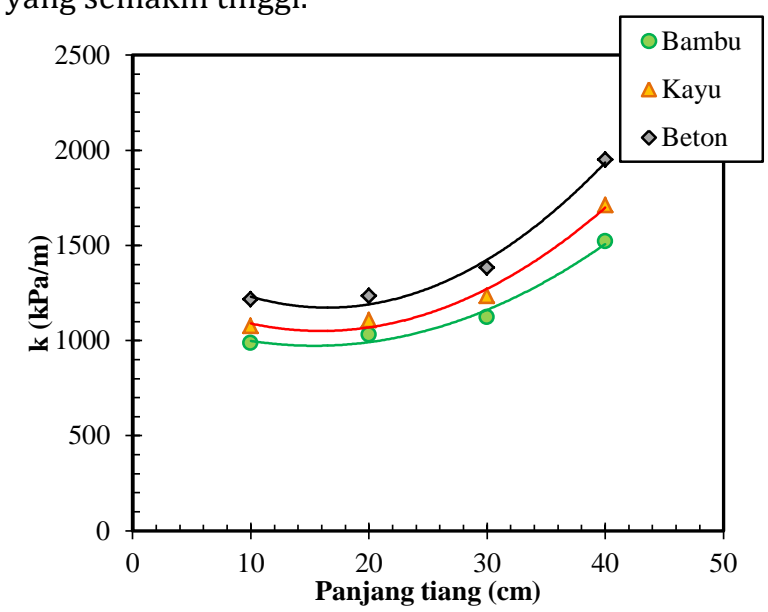

Gambar 9. Modulus Reaksi Tanah Dasar pada Setiap Panjang Tiang

Peningkatan nilai $\mathrm{k}$ terlihat jelas pada tiang dengan panjang $30 \mathrm{~cm}$. Peningkatan nilai k yang signifikan terjadi pada tiang dengan panjang $40 \mathrm{~cm}$ untuk semua jenis tiang yang digunakan. Nilai $\mathrm{k}$ pada pelat yang diperkuat tiang beton terlihat lebih tinggi dari tiang kayu dan tiang bambu. Ini dapat terjadi, karena kapasitas dukung pelat yang diperkuat tiang beton lebih tinggi dari tiang lainnya. Kapasitas dukung yang tinggi berpengaruh pada peningkatan nilai $\mathrm{k}$.

Peningkatan modulus reaksi tanah-dasar pada pelat akibat perkuatan tiang dapat dilihat pada Tabel 4. Peningkatan nilai $\mathrm{k}$ akibat pemasangan tiang pada pelat didapatkan 31-103\% untuk tiang bambu, 44-128\% untuk tiang kayu, dan $62-160 \%$ untuk tiang beton. Tiang yang dipasang monolit pada pelat memperlihatkan peningkatan pada nilai modulus reaksi tanah-dasar (k), hal ini sama dengan hasil penelitian [13]. Tiang monolit memberikan pengaruh yang baik pada kinerja tiang dengan pelat. Kombinasi tiang dengan pelat dalam satu kesatuan memberikan dukungan pada beban yang lebih baik dibandingkan dengan tiang yang tidak monolit. Hal ini ditunjukkan pada nilai kuat dukung yang lebih tinggi dan pada akhirnya memberikan nilai k yang lebih tinggi juga.

Tabel 4. Peningkatan modulus reaksi tanah-dasar pada akibat perkuatan tiang

\begin{tabular}{cccc}
\hline \multirow{2}{*}{$\begin{array}{c}\text { Panjang } \\
\text { tiang (cm) }\end{array}$} & \multicolumn{3}{c}{ Peningkatan nilai k (\%) } \\
\cline { 2 - 4 } & $\begin{array}{c}\text { Tiang } \\
\text { bambu }\end{array}$ & $\begin{array}{c}\text { Tiang } \\
\text { kayu }\end{array}$ & $\begin{array}{c}\text { Tiang } \\
\text { beton }\end{array}$ \\
\hline 10 & 31 & 44 & 62 \\
20 & 37 & 48 & 64 \\
30 & 50 & 64 & 84 \\
40 & 103 & 128 & 160 \\
Rata-rata (\%) & 55 & 71 & 93 \\
\hline
\end{tabular}

Nilai $\mathrm{k}$ berhubungan dengan nilai $\mathrm{q}_{\mathrm{u}}$, hal ini terlihat pada hubungan kapasitas dukung dengan modulus reaksi tanah-dasar yang ditunjukkan pada Gambar 10. Kurva $\mathrm{q}_{\mathrm{u}}$-k membentuk pola polinomial 
atau nonlinier. Nilai $\mathrm{q}_{\mathrm{u}}$ yang tinggi memperlihatkan nilai $\mathrm{k}$ yang tinggi juga. Ini menunjukkan bahwa nilai $\mathrm{k}$ berbanding lurus dengan nilai $\mathrm{q}_{\mathrm{u}}$ dan berbanding terbaik dengan $\delta$.

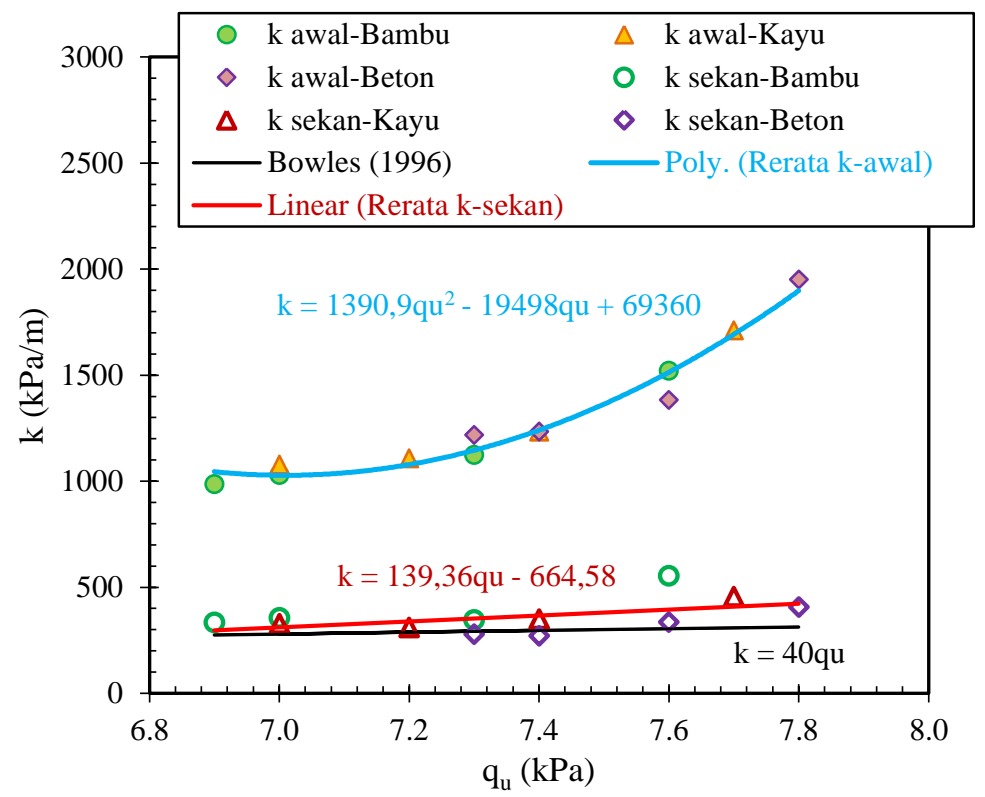

Gambar 10. Hubungan Kapasitas Dukung dengan Modulus Reaksi Tanah-Dasar

Rata-rata perbandingan $\mathrm{k}_{\text {awal }}$ dan $\mathrm{q}_{\mathrm{u}}$ diperoleh sebesar 175 , sedangkan perbandingan $\mathrm{k}_{\text {sekan }}$ dan $\mathrm{q}_{\mathrm{u}}$ diperoleh sebesar 49 . Berdasarkan perbandingan ini, maka nilai $\mathrm{k}_{\mathrm{awal}}$ dan nilai $\mathrm{k}_{\text {sekan }}$ dapat diperoleh dari nilai $\mathrm{q}_{\mathrm{u}}$, seperti pada Persamaan (4) dan Persamaan (5). Nilai $k_{\text {sekan }}$ mendekati sama dengan nilai $\mathrm{k}$ dari Bowles [18], seperti pada Persamaan (3).

$k_{\text {awal }}=175 q_{u}$

$k_{\text {sekan }}=49 q_{u}$

Hasil analisis kapasitas dukung dapat digunakan sebagai dasar dalam perancangan pondasi maupun pelat sebagai perkerasan kaku pada pekerjaan jalan. Kapasitas dukung menyatakan tahanan geser tanah dalam melawan penurunan akibat pembebanan [15].

Nilai modulus reaksi tanah-dasar diperlukan dalam menganalisis struktur pondasi yang berinteraksi dengan sistem dukungan elastis seperti tanah, selain itu dapat juga digunakan dalam perancangan pondasi memanjang dan pondasi tiang [15].

\section{KESIMPULAN}

Nilai kapasitas dukung pelat akibat perkuatan tiang bambu didapatkan sebesar 6,9-7,6 $\mathrm{kPa}$, tiang kayu antara 7-7,7 kPa, dan tiang beton antara 7,3-7,8 kPa. Kapasitas dukung meningkat $20 \%$ untuk tiang bambu, $22 \%$ untuk tiang kayu, dan $25 \%$ untuk tiang beton dari kapasitas dukung pelat tanpa tiang sebesar $6 \mathrm{kPa}$. Peningkatan kapasitas dukung dipengaruhi oleh panjang tiang dan jenis material tiang yang digunakan. Tiang beton memberikan peningkatan kapasitas dukung pelat dari jenis tiang lainnya.
Modulus reaksi tanah-dasar pada pelat yang didukung oleh tiang didapatkan lebih tinggi dari pelat tanpa tiang. Peningkatan nilai $\mathrm{k}$ yang signifikan terjadi pada tiang dengan panjang $40 \mathrm{~cm}$ atau $80 \%$ dari tebal lapisan tanah untuk semua jenis tiang yang digunakan. Peningkatan tertinggi untuk tiang bambu sebesar 103\%, tiang kayu 128\%, dan tiang beton sebesar 160\%. Tiang beton menghasilkan kinerja yang baik dalam meningkatkan kapasitas dukung dan modulus reaksi tanah-dasar. Ini membuktikan tiang beton lebih kokoh dan kuat dalam memikul beban.

Hubungan kapasitas dukung dengan modulus reaksi tanah-dasar akibat penambahan tiang membentuk pola non linier. Nilai modulus reaksi tanah-dasar semakin tinggi seiring dengan peningkatan kapasitas dukung dan pengurangan defleksi. Hasil penelitian ini menunjukkan nilai modulus reaksi tanah-dasar yang tinggi pada penurunan maksimum $20 \%$ dari diameter pelat.

\section{UCAPAN TERIMA KASIH}

Tim penulis mengucapkan terima kasih kepada pihak-pihak yang berkontribusi dalam penelitian ini. Utamanya kepada teknisi laboratorium dan kepala laboratorium Mekanika Tanah Jurusan Teknik Sipil - Institut Teknologi Medan.

\section{REFERENSI}

[1] F. Syarif, G. M. Davino, and M. F. Ardianto, "Penerapan Teknik Biocementation Oleh Bacillus Subtilis dan Pengaruhnya Terhadap Permeabilitas Pada Tanah Organik," J. Saintis, vol. 20, no. 1, pp. 47-52, 2020, doi: 10.25299/saintis2020.vol20(01).4809. 
[2] A. Waruwu, H. C. Hardiyatmo, and A. Rifa'i, "Compressive Behavior of BagansiapiapiRiau Peat in Indonesia," Electron. J. Geotech. Eng., vol. 21, no. 16, pp. 5217-5227, 2016.

[3] S. Kazemian, A. Asadi, B. B. K. Huat, A. Prasad, and I. B. A. Rahim, "Settlement Problems in Peat Due to Their High Compressibility and Possible Solution Using Cement Columns," in Forensic Engineering Congress, 2009, pp. 255-264.

[4] M. Yusuf and A. Aryanto, "Kajian Pengaruh Konfigurasi Kelompok Tiang Terhadap Daya Dukung Tanah untuk Perkuatan Fondasi Jalan di Tanah Gambut," J. Tek. Sipil Untan, vol. 11, no. 1, pp. 53-64, 2011.

[5] C. Tamara and F. Fahriani, "Analisis Konfigurasi Tiang Pancang Kelompok Terhadap Daya Dukung dan Penurunan Tiang," J. Fropil, vol. 5, no. 2, pp. 69-86, 2017.

[6] C. Kurniawan, P. Sebayang, and M. Muljadi, "Pembuatan beton high-strength berbasis mikrosilika dari abu vulkanik Gunung Merapi," J. Ilmu Pengetah. dan Teknol. TELAAH, vol. 29, no. 1, pp. 15-21, 2011.

[7] F. Saddek, M. Muhadi, and F. Fatnanta, "Analisis Daya Dukung pada Tanah Gambut dan Lanau Menggunakan Cerucuk Kayu Mahang," Jom FTEKNIK, vol. 5, no. 1, pp. 1$13,2018$.

[8] A. Waruwu, H. C. Hardiyatmo, and A. Rifa'i, "Studi Eksperimental Pembebanan Pelat yang Diperkuat Tiang pada Tanah Gambut," in Seminar Nasional Geoteknik 2016 HATTI Yogyakarta, 2016, pp. 53-59.

[9] A. Waruwu, H. C. Hardiyatmo, and A. Rifa'i, "Behavior of Nailed-Slab System on Peat Soil Under Laoding," in The 1st Warmadewa University International Conference on Architecture and Civil Engineering, 2017, pp. 91-97.

[10] A. Waruwu, H. C. Hardiyatmo, and A. Rifa'i, "The Performance of The Nailed Slab System-Supported Embankment on Peat Soil," Int. Rev. Civ. Eng., vol. 10, no. 5, pp. 243-248, 2019, doi: 10.15866/irece.v10i5.15757.

[11] A. Waruwu, R. D. Susanti, D. Endriani, and S. Hutagaol, "Effect of Loading Stage on Peat Compression and Deflection of Bamboo Grid with Concrete Pile," Int. J. GEOMATE, vol. 18, no. 66, pp. 150-155, 2020, doi: 10.21660/2020.66.62072.

[12] A. Waruwu, R. D. Susanti, H. S. Sihombing, and T. Y. Purba, "Pengaruh Susunan Tiang dengan Grid Bambu pada Tanah Gambut Terhadap Lendutan," in Semnastek UISU, 2020, pp. 9-15.

[13] A. Waruwu, H. C. Hardiyatmo, and A. Rifa'i, "Deflection Behavior of The Nailed Slab System-Supported Embankment on Peat Soil," J. Appl. Eng. Sci., vol. 15, no. 4, pp. 556-
563, 2017, doi: 10.5937/jaes15-15113.

[14] A. Waruwu, H. C. Hardiyatmo, and A. Rifa'i, "Uji Beban Timbunan yang Diperkuat dengan Sistem Pelat Terpaku pada Tanah Gambut," Media Komun. Tek. Sipil, vol. 25, no. 2, pp. 152-159, 2019, doi: 10.14710/mkts.v25i2.21018.

[15] H. C. Hardiyatmo, Analisis dan Perancangan Fondasi I. Yogyakarta: Gadjah Mada University Press, 2011.

[16] B. M. Das, Principles of Geotechnical Engineering. Stamford USA: Cengage Learning, 2010.

[17] C. Venkatramaiah, Geotechnical Engineering. New Delhi India: New Age International Publishers, 2006.

[18] J. E. Bowles, Foundation Analysis and Design. Tokyo, Japan: McGraw-Hill Kogakusha, Ltd, 1996.

\section{NOMENKLATUR}

P beban

A luas permukaan pelat

$\delta \quad$ defleksi atau penurunan rata-rata

$\delta_{\mathrm{o}} \quad$ defleksi pada pelat tanpa tiang

$\sigma \quad$ tekanan

$\mathrm{q}_{\mathrm{u}} \quad$ kapasitas dukung ultimit

$\mathrm{k}$ modulus reaksi tanah-dasar

$\Delta \mathrm{k}$ tambahan modulus reaksi tanah-dasar

k' modulus reaksi tanah-dasar ekivalen

d diameter tiang

L panjang tiang 